\title{
ASEAN-KANADA FREE TRADE AGREEMENT (FTA): PELUANG BAGI INDONESIA
}

\author{
ASEAN-Canada Free Trade Agreement (FTA): An opportunity for \\ Indonesia
}

\author{
Steven Raja Ingot, Dian Dwi Laksani

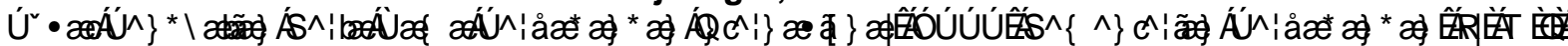

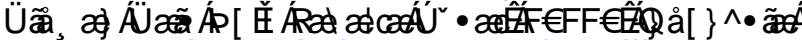 \\ ( IP DLOVWEDNR\# JP DLOFRP W \\ [

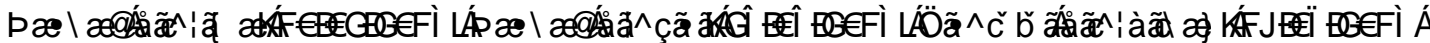

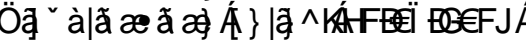

\begin{abstract}
Abstrak

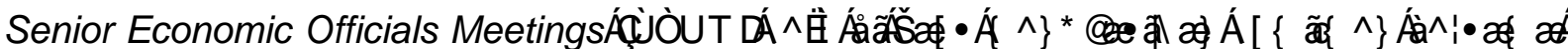

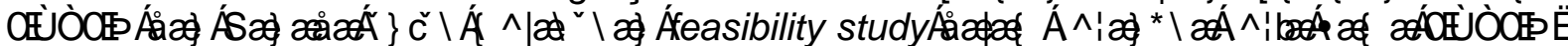
. DQDGD ) 7 \$ 3 HQHOWDQ LQ EHUXXXDQ XQXNN P HQJ KIUXQJ GDP SDN SHUDQNDQ SHEDJDQJDQ EDUDQJ], QGRQHMDI SDGD \$ 6 ( \$1. DQDGD) 7\$ \$ GHQJDQ P RGHODQDQMVI Computable General

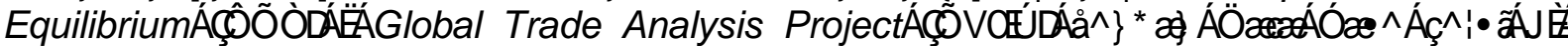

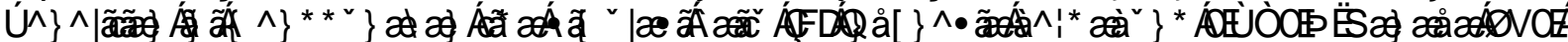

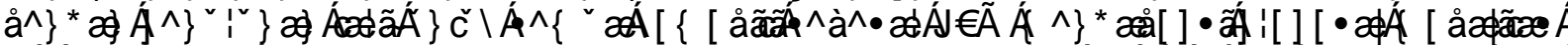

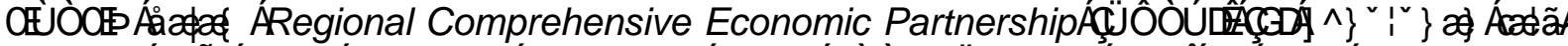

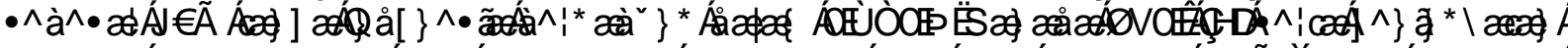

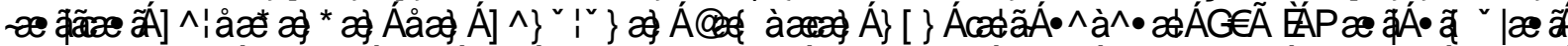

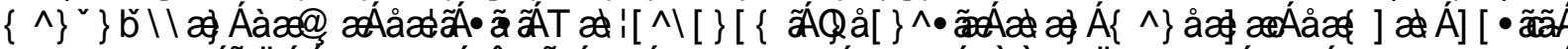

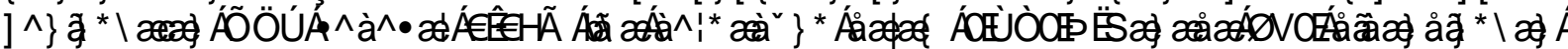

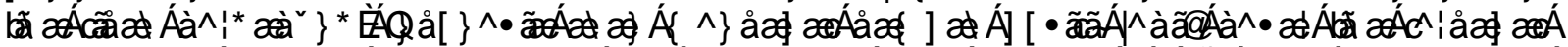

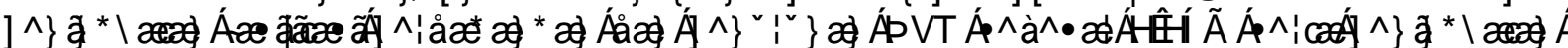

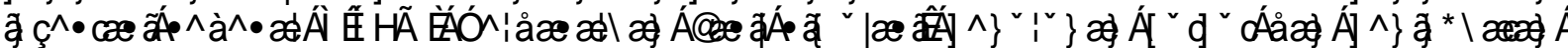

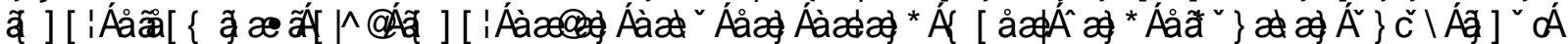

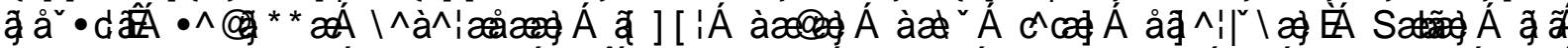

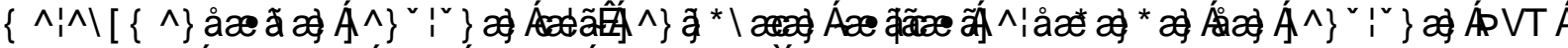
P HUKSDNDQN FINENDQI DQJIMDQJ DUAG HERDQW
\end{abstract}

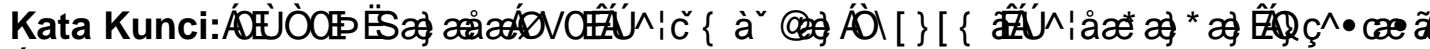
प]

\section{Abstract}

At the 8th ASEAN Economic Senior Review Official Meetings (SEOM) in Laos, ASEAN and Canada committed to conduct a feasibility study within the framework of ASEAN-Canada FTA. This study aims to measures the impact of ASEAN-Canada FTA implementation to Indonesia using Computable General Equilibrium (CGE) model - the 9th version of Global Trade Analysis Project (GTAP). The study run three different simulations (1) Indonesia joining the ASEAN-Canada with a 90\% tariff reduction applied to all goods adopting ASEAN modality in Regional Comprehensice Economic Partnership (RCEP); (2) 90\% Tariff reduction without Indonesia joining the ASEAN-Canada FTA, (3) improving trade facilitation and decreasing $20 \%$ non-tariff measures. Simulation result shown that from Macroeconomic perspective, Indonesia will get positive impact of increasing $0.03 \%$ GDP by joining the FTA instead of not joining. Indonesia will get higher impact by increasing trade facilitation and $8.53 \%$ investment and reducing $3.35 \%$ of NTM. Based on the results, the declining output and increasing import is dominated by import of raw materials and capital goods, therefore import of raw material remain important. This study recommended reducing tariff and NTM as well as improving trade facilitation are necessary for Indonesia. 
Keywords: ASEAN-Canada FTA, Economic Growth, Trade, Investment

JEL Classification: F12, F13, F15

\section{PENDAHULUAN}

Pada pertemuan Senior Economic Officials Meetings (SEOM) ke-8, tanggal 30 Juni 2016 di Laos, ASEANKanada menyepakati adanya feasibility study untuk kerangka kerja sama ASEAN-Kanada Free Trade Aggrement (ASEAN-Kanada FTA). Sehubungan dengan hal tersebut maka Indonesia melakukan studi internal mengenai biaya dan manfaat bagi Indonesia. Diharapkan dari hasil analisis dapat dijadikan bahan pertimbangan posisi dan strategi Indonesia dalam menanggapi usulan pembentukan kerja sama perdagangan ASEAN-Kanada FTA.

Beberapa kajian biaya manfaat ASEAN dan khususnya Indonesia mengenai dampak kerja sama dengan mitra negaranya diantaranya dilakukan oleh Furkon (2015) yang bertujuan untuk menganalisis dampak perjanjian ASEAN Korea FTA terhadap kondisi ekonomi global, makroekonomi, persaingan antar region dan kondisi sektoral/komoditi bagi Indonesia. Penelitian ini dianalisis menggunakan metode Global Trade Analysis Project (GTAP Versi 9). Hasil penelitiannya menunjukkan bahwa: (i) perjanjian kerjasama ASEAN-Korea FTA secara umum berdampak positif terhadap perekonomian global; (ii) pada sisi makroekonomi, perjanjian kerja sama tersebut akan memberikan manfaat bagi Indonesia. Manfaat tersebut berupa peningkatan PDB, kesejahteraan regional, dan neraca perdagangan. Hidayat (2016) melakukan kajian yang berjudul Dinamika Kerja sama Ekonomi Indonesia Dengan Anggota Organisasi Konferensi Islam (OKI): Potensi dan Pengaruhnya terhadap Perekonomian Indonesia. Hasil kajian menunjukkan OKI berpotensi menjadi pasar potensial bagi produk ekspor Indonesia saat ini dan di masa mendatang. Skema liberalisasi perdagangan yang dibuat oleh OKI melalui Trade Preferential System of the Organization of the Islamic Conferences (TPS-OIC) merupakan saluran awal untuk membuka akses menuju integrasi ekonomi yang lebih dalam. Hasil simulasi dengan model GTAP menunjukkan bahwa liberalisasi perdagangan negara-negara OKI memberikan dampak sektoral yang variatif. Indonesia berpotensi 
mendapatkan manfaat besar jika liberalisasi perdagangan dalam OKI dilakukan secara komprehensif/full liberalization (meliputi semua komoditas dan pengurangan tarif secara penuh). Laksani \& Salam (2016) menganalisis perkiraan dampak ASEAN Hong Kong Free Trade Area (AHKFTA) terhadap Kinerja Perdagangan. Hasil penelitian menunjukkan Penurunan tarif 50\% dalam ASEAN - Hong Kong berdampak pada penurunan kesejahteraan di seluruh negara kecuali Laos. Jika dilakukan full liberalisasi, seluruh negara meningkat kesejahteraannya kecuali Laos. Jika dilakukan full liberalisasi, seluruh negara meningkat kesejahteraannya. Selain dampak terhadap kesejahteraan, penurunan tarif $50 \%$ berdampak pada penurunan GDP riil di seluruh negara ASEAN kecuali Hong Kong (meningkat kurang dari $1 \%$ ). Jika full liberalisasi, manfaat ASEAN Hong Kong FTA diprediksi akan meningkatkan GDP riil di seluruh negara ASEAN, dua tertinggi Vietnam dan Thailand. Hong Kong mengalami penurunan GDP riil kurang dari $1 \%$. Indonesia sendiri memperoleh manfaat peningkatan GDP yang relatif kecil. Hal ini dimungkinkan karena insentif liberalisasi perdagangan hanya terjadi pada beberapa sektor yang merupakan komoditi unggulan ekspor seperti vegetable oil (vol), oil seeds (osd), wearring apparel (wap), textile (tex) dan electronic equipment (ele). Indonesia perlu melakukan suatu upaya peningkatan daya saing bagi sektor yang berdaya saing rendah agar manfaat dari kerja sama dapat terjadi di seluruh sektor.

Oleh karena itu, Indonesia saat ini tengah melakukan proses perundingan dalam kerangka ASEAN-Kanada FTA serta fokus pada Indonesia - European Union Comprehensive Economic Partnership Agreement (Indonesia-EU CEPA) untuk dapat meningkatkan pangsa pasar, transfer teknologi dan menciptakan perdagangan yang lebih stabil antara Indonesia dan Uni Eropa (Manurung, 2016).

Selain itu ada beberapa kajian tentang dampak kerja sama ASEANKanada FTA telah dilakukan dan dipublikasikan oleh beberapa Lembaga penelitian antara lain Centre for Strategic and International Studies (CSIS), Institute of Southeast Asian Studies (ISEAS), Canada-ASEAN Business Council, dan Economic Research Institute for ASEAN and East Asia (ERIA) yang saat ini sedang menyelesaikan Joint Feasibility Study ASEAN-Kanada FTA. ASEAN-Kanada 
FTA merupakan salah satu opsi yang dianjurkan untuk diambil oleh Kanada untuk menghilangkan dampak negatif bagi Kanada dari diterapkannya beberapa kerja sama FTA ASEAN+1 dan kemungkinan dikembangkannya East Asia FTA (EAFTA) (Soesastro, 2005) menunjukkan bahwa kerja sama perdagangan FTA ASEAN+1 akan memberikan dampak negatif pada negara-negara mitra dagang ASEAN diluar wilayah Asia Timur, salah satunya Kanada.

Dampak positif dari kerja sama perdagangan ASEAN-Kanada FTA juga ditunjukkan oleh Woo (2005). Dengan menggunakan Computable General Equlibrium (CGE), kerja sama ASEANKanada FTA diprediksi akan memberikan manfaat positif bagi seluruh negara anggotanya. Namun demikian, magnitude dampaknya diprediksi tidak besar. Hasil estimasi yang positif dari ASEAN-Kanada FTA yang ditunjukkan oleh beberapa penelitian di atas, menjadi argumen dasar Barichello \& Yap (2010) dalam menekankan pentingnya analisis yang komprehensif tentang feasibility dari ASEAN-Kanada FTA atau comprehensive economic partnership agreement antara kedua pihak.
Studi terkini tentang dampak ASEAN-Kanada FTA baru-baru ini dipublikasikan oleh Canada-ASEAN Business Council (CABC) dalam laporannya yang berjudul "The ASEAN Advantage: Report on the Impact of a Canada-ASEAN FTA". Hasil studi CABC (2017) menunjukkan adanya potensi meningkatkan perdagangan bilateral sebesar 4,8 sampai dengan 10,9 miliar Dollar Kanada (CAD). Output nasional Kanada diperkirakan akan meningkat sebesar 1,2 miliar CAD pada tahun 2027. Manfaat positif juga diprediksi akan dirasakan oleh ASEAN dengan peningkatan GDP sebesar 1,8 miliar CAD (penjumlahan GDP 10 negara ASEAN).

Penelitian ini bertujuan untuk menghitung manfaat makro ekonomi ASEAN - Kanada FTA bagi perekonomian Indonesia. Kami melakukan penghitungan yang bersifat statis yaitu menghitung manfaat dari kerja sama perdagangan ASEAN Kanada FTA ditinjau dari makro ekonomi yaitu GDP dan dari sektoral ekonomi tanpa memperhitungkan perubahan yang terjadi dari variabelvariabel ekonomi yang mempengaruhi perdagangan. Permasalahan yang ingin dijawab dalam penelitian ini adalah 
seberapa besar manfaat yang akan diperoleh Indonesia dengan adanya ASEAN-Kanada FTA. Diharapkan kerja sama ini dapat memperluas pasar produk-produk ASEAN khususnya Indonesia ke pasar Kanada. Tulisan ini bertujuan untuk mengidentifikasi manfaat dari penurunan hambatan baik tarif maupun non-tariff terhadap Indonesia di kawasan ASEAN-Kanada FTA. Perbedaan dari studi ini dengan studi-studi sebelumnya adalah dari simulasi CGE yang digunakan. Dalam studi ini digunakan tiga simulasi yaitu penurunan tarif sebesar $90 \%$ serta peningkatan fasilitasi perdagangan dan penurunan hambatan Non Tarif.

\section{METODE}

Pemilihan model Multi-Region Computable General Equlibrium (CGE) di dalam analisis ini dikarenakan tujuan penelitian ini adalah untuk menghitung seberapa besar manfaat berlakunya perjanjian perdagangan barang ASEAN-Kanada FTA terhadap kinerja perdagangan Indonesia, dimana analisis ini memproyeksikan dampak ekonomi ketika berlakunya ASEANKanada FTA atau dengan kata lain analisis ex-ante (Raihan, 2015). Hal ini dipertegas dengan penelitian Plummer, Cheong \& Hamaka (2010) dalam Yuventus (2014) yang menyatakan bahwa evaluasi perjanjian perdagangan bebas dapat dilakukan sebelum dan setelah implementasi FTA, dimana Computable General Equilibrium (CGE) dapat digunakan sebagai analisis exante implementasi FTA sedangkan untuk ex post dapat diukur dengan menggunakan model gravitasi.

Penelitian ini menggunakan data sekunder yang diperoleh dari Word Trade Organization, Badan Pusat Statistik, Kementerian Perdagangan dan Trade Map. Data terkait variabel makroekonomi bersumber dari Bank Indonesia, UNCTAD dan lain sebagainya. Selain data-data sekunder tersebut, digunakan pula data yang bersumber dari basis data GTAP versi 9 yang diterbitkan tahun 2015 yang sudah disempurnakan dari versi sebelumnya dengan pembagian region menjadi 140 region, 57 Sektor dan tahun referensi 2004, 2007 dan 2011 (Aguiar, Narayanan \& McDougall, 2016). Agregasi negara yang digunakan adalah negara-negara yang tergabung dalam ASEAN-Kanada (Tabel 1). 
Tabel 1. Agregasi negara untuk Skema FTA ASEAN-Kanada FTA

\begin{tabular}{|c|c|c|c|}
\hline No. & Kode & Nama & Keterangan \\
\hline 1 & Indonesia & Indonesia & Indonesia. \\
\hline 2 & Malaysia & Malaysia & Malaysia. \\
\hline 3 & Filipina & Filipina & Filipina. \\
\hline 4 & Singapura & Singapura & Singapura. \\
\hline 5 & Thailand & Thailand & Thailand. \\
\hline 6 & Vietnam & Vietnam & Vietnam \\
\hline 7 & BruneiD & Brunei & Brunei Darussalam \\
\hline 8 & Kamboja & Kamboja & Kamboja \\
\hline 9 & Laos & Laos & Laos \\
\hline 10 & Kanada & Kanada & Kanada \\
\hline 11 & ROW & $\begin{array}{l}\text { All other } \\
\text { regions }\end{array}$ & $\begin{array}{l}\text { China; Korsel; Australia; New Zealand; Rest of Oceania; } \\
\text { Hong Kong; Japan; Taiwan; Rest of East Asia; Rest of } \\
\text { Southeast Asia; Bangladesh; India; Sri Lanka; Rest of } \\
\text { South Asia; United States; Mexico; Rest of North } \\
\text { America; Colombia; Peru; Venezuela; Rest of Andean } \\
\text { Pact; Argentina; Brazil; Chile; Uruguay; Rest of South } \\
\text { America; Central America; Rest of FTAA; Rest of the } \\
\text { Caribbean; Austria; Belgium; Denmark; Finland; } \\
\text { France; Germany; United Kingdom; Greece; Ireland; } \\
\text { Italy; Luxembourg; Netherlands; Portugal; Spain; } \\
\text { Sweden; Switzerland; Rest of EFTA; Rest of Europe; } \\
\text { Albania; Bulgaria; Croatia; Cyprus; Czech Republic; } \\
\text { Hungary; Malta; Poland; Romania; Slovakia; Slovenia; } \\
\text { Estonia; Latvia; Lithuania; Russian Federation; Rest of } \\
\text { Former Soviet Union; Turkey; Rest of Middle East; } \\
\text { Morocco; Tunisia; Rest of North Africa; Botswana; } \\
\text { South Africa; Rest of South African CU; Malawi; } \\
\text { Mozambique; Tanzania; Zambia; Zimbabwe; Rest of } \\
\text { SADC; Madagascar; Uganda; Rest of Sub-Saharan } \\
\text { Africa. }\end{array}$ \\
\hline
\end{tabular}

Sedangkan agregasi sektornya GTAP versi 9. 57 sektor dalam diambil berdasarkan 57 sektor dalam penelitian ini dapat dilihat pada Tabel 2. 
Tabel 2. Agregasi Sektor pada Skema Kerja sama FTA ASEAN-Kanada

\begin{tabular}{|c|c|c|c|c|c|}
\hline \multirow{2}{*}{ No. } & \multirow{2}{*}{ Kode } & \multirow{2}{*}{$\begin{array}{c}\text { Deskripsi } \\
\text { Sektor }\end{array}$} & \multirow{2}{*}{ No. } & \multirow{2}{*}{ Kode } & Deskripsi \\
\hline & & & & & Sektor \\
\hline 1 & $\mathrm{pdr}$ & Paddy rice & 30 & mil & Dairy products \\
\hline 2 & wht & Wheat & 31 & pcr & Processed rice \\
\hline 3 & gro & Cereal grains nec & 32 & sgr & Sugar \\
\hline 4 & $v \_f$ & Vegetables, fruit, nuts & 33 & ofd & Food products nec \\
\hline 5 & osd & Oil seeds & 34 & b_t & Beverages and tobacco products \\
\hline 6 & c_b & Sugar cane, sugar beet & 35 & tex & Textiles \\
\hline 7 & $\mathrm{Pfb}$ & Plant-based fibers & 36 & wap & Wearing apparel \\
\hline 8 & Ocr & Crops nec & 37 & lea & Leather products \\
\hline 9 & Ctl & Cattle, sheep, goats, horses & 38 & lum & Wood products \\
\hline 10 & oap & Animal products nec & 39 & $\mathrm{ppp}$ & Paper products, publishing \\
\hline 11 & rmk & Raw milk & 40 & p_c & Petroleum, coal products \\
\hline 12 & wol & Wool, silk-worm cocoons & 41 & crp & Chemical, rubber, plastic prods \\
\hline 13 & Frs & Forestry & 42 & $\mathrm{nmm}$ & Mineral products nec \\
\hline 14 & Fsh & Fishing & 43 & i_s & Ferrous metals \\
\hline 15 & coa & Coal & 44 & $\mathrm{nfm}$ & Metals nec \\
\hline 16 & Oil & Oil & 45 & fmp & Metal products \\
\hline 17 & gas & Gas & 46 & $\mathrm{mvh}$ & Motor vehicles and parts \\
\hline 18 & omn & Minerals nec & 47 & otn & Transport equipment nec \\
\hline 19 & $\mathrm{cmt}$ & Meat: cattle, sheep, goats, horse & 48 & ele & Electronic equipment \\
\hline 20 & omt & Meat products nec & 48 & ome & Machinery and equipment nec \\
\hline 21 & vol & Vegetable oils and fats & 50 & omf & Manufactures nec \\
\hline 22 & Ely & Electricity & 51 & $\mathrm{cmn}$ & Communication \\
\hline 23 & gdt & Gas manufacture, distribution & 52 & ofi & Financial services nec \\
\hline 24 & Wtr & Water & 53 & isr & Insurance \\
\hline 25 & cns & Construction & 54 & obs & Business services nec \\
\hline 26 & Trd & Trade & 55 & ros & Recreation and other services \\
\hline 27 & Otp & Transport nec & 56 & osg & PubAdmin/Defence/Health/ Educat \\
\hline 28 & Wtp & Sea transport & 57 & dwe & Dwellings \\
\hline 29 & Atp & Air transport & & & \\
\hline
\end{tabular}

$\begin{array}{lrl}\text { Model GTAP adalah model } & \text { ekonomi dan komponen-komponen } \\ \text { ekonomi keseimbangan umum } & \text { permintaan akhir di suatu negara dan } \\ \text { (Computable General Equilibrium } & \text { antar negara. Penekanan GTAP terletak } \\ \text { (CGE)) dengan banyak negara dan } & \text { pada keterkaitan perekonomian secara } \\ \text { banyak komoditas (Oktaviani \& } & \text { keseluruhan, sehingga dapat digunakan } \\ \text { Puspitawati, 2017). Seperti model CGE } & \text { untuk menganalisis dampak perubahan } \\ \text { lainnya, di dalam model GTAP } & \text { kebijakan suatu negara terhadap } \\ \text { dijelaskan keterkaitan antar agen-agen } & \text { perekonomian sektoral maupun makro }\end{array}$


di negara tersebut dan negara lainnya. Pada model GTAP secara eksplisit dilakukan permodelan dalam margin transportasi internasional. Suatu global bank juga dibentuk dalam model sebagai intermediasi dari investasi dan tabungan dunia. Sistem permintaan konsumen dihitung dengan menggunakan Constant Difference of Elasticities (CDE) untuk menangkap kepekaan terhadap perbedaan harga dan pendapatan antar negara (Hertel, 1997).

Selain itu, aliran barang dalam perdagangan internasional mengikuti model Armington (1969) dimana setiap produk dibedakan berdasarkan asal negara. Setiap komoditas impor diasumsikan bersubstitusi tidak sempurna satu sama lainnya dengan komoditas yang diproduksi di dalam negeri. Dengan asumsi ini, model dapat menangkap aliran perdagangan antar dua negara. Kelemahan model ini adalah mengasumsikan sistem pasar persaingan sempurna dan skala usaha yang konstan pada aktivitas produksi. Pada konteks negara kecil dan terbuka, asumsi pasar persaingan sempurna mengakibatkan simulasi dampak penurunan tarif menjadi lebih besar dari yang sesungguhnya (Hertel, 1997).
Model GTAP standar diolah menggunakan software RunGTAP. Proses agregasi sektor dan negara/ wilayah dilakukan menggunakan GTAPAgg. Proses pengolahan data dengan RunGTAP akan dilakukan dengan melakukan penyesuaian closure dan shock sesuai dengan tujuan penelitian. Olahan data ini akan menghasilkan analisis dampak makro ekonomi seperti GDP dan Investasi serta analisis dampak sektoral.

\section{HASIL DAN PEMBAHASAN}

Kerangka kerja sama ASEANKanada FTA diharapkan mampu memberikan manfaat tidak hanya bagi ASEAN dan Kanada secara keseluruhan namun Indonesia sebagai suatu entitas ekonomi akan memperoleh keuntungan. Untuk dapat mengetahui bagaimana dampak skema perdagangan tersebut, maka dengan menggunakan data dan model GTAP digunakan beberapa simulasi.

Simulasi 1, dimana seluruh negara ASEAN bergabung dalam ASEANKanada FTA dengan tingkat penurunan tarif untuk semua komoditi sebesar $90 \%$. Pada simulasi 2, seluruh negara ASEAN kecuali Indonesia bergabung dalam ASEAN-Kanada FTA dengan tingkat penurunan tarif untuk semua 
komoditi sebesar $90 \%$. Penurunan tarif sebesar $90 \%$ diadopsi dari proposal modalitas ASEAN dalam RCEP (Regional Comprehensive Economic Partnership) per 29 Januari 2018.

Pada simulasi 3, lebih berfokus pada peningkatan fasilitasi perdagangan dan penurunan hambatan non-tarif sebesar $20 \%$ mengacu pada Joint Feasibility Study ASEAN - Canada oleh ERIA (2018). Menurut Itakura (2014), pengurangan hambatan perdagangan akan dapat memberikan dampak positif terhadap ekonomi suatu negara. Simulasi non tarif, menggunakan data kuantifikasi Non Tarif Measures (NTM) dari studi Kenichi (2014). Kenichi (2014) telah mengkuantifikasikan besaran Non Tarif Measures (NTM) untuk beberapa produk dan negara di kawasan Asia Pasifik.

\section{Kinerja Perdagangan}

Pada tahun 2016 total nilai ekspor ASEAN ke Kanada mencapai USD 8,48 miliar, sedangkan total nilai impor ASEAN dari Kanada sebesar USD 5,13 miliar. Selama periode 2012-2016, secara umum mayoritas negara anggota ASEAN sudah mengalami surplus perdagangan dengan Kanada, namun untuk Indonesia, Brunei Darussalam, dan Singapura ternyata masih mengalami defisit perdagangan pada tahun 2016. Kamboja dan Vietnam merupakan dua negara anggota ASEAN memiliki kinerja perdagangan meningkat secara progresif baik dari indikator total perdagangan maupun neraca perdagangan. Sementara itu, pada tahun 2015 Indonesia merupakan negara yang memiliki total perdagangan terbesar ke-3 dengan Kanada dibandingkan dengan negara ASEAN lainnya. Negara yang memiliki total perdagangan terkecil dengan Kanada adalah Myanmar, Laos dan Brunei Darussalam. Perkembangan neraca perdagangan ASEAN dan Kanada dapat dilihat pada Tabel 3 . 
Tabel 3. Kondisi Umum Perdagangan Indonesia, Negara ASEAN dan Kanada (dalam ribu USD)

\begin{tabular}{|c|c|c|c|c|c|}
\hline \multirow{2}{*}{ Negara } & \multicolumn{5}{|c|}{ Tahun } \\
\hline & 2012 & 2013 & 2014 & 2015 & 2016 \\
\hline \multicolumn{6}{|l|}{ Filipina } \\
\hline Neraca perdagangan & 75,731 & 39,153 & 261,452 & 169,307 & 105,918 \\
\hline Total Perdagangan & 840,639 & $1,037,759$ & 933,682 & 957,689 & 941,914 \\
\hline \multicolumn{6}{|l|}{ Indonesia } \\
\hline Neraca perdagangan & $-1,018,300$ & $-1,285,124$ & $-1,105,177$ & $-886,907$ & $-650,458$ \\
\hline Total Perdagangan & $2,603,192$ & $2,849,818$ & $2,615,219$ & $2,311,597$ & $2,115,602$ \\
\hline \multicolumn{6}{|l|}{ Brunei Darussalam } \\
\hline Neraca perdagangan & $-11,534$ & $-7,300$ & 209,972 & $-4,758$ & $-10,162$ \\
\hline Total Perdagangan & 13,244 & 11,680 & 277,692 & 6,072 & 11,784 \\
\hline \multicolumn{6}{|l|}{ Kamboja } \\
\hline Neraca perdagangan & 388,714 & 453,330 & 495,714 & 520,277 & 604,961 \\
\hline Total Perdagangan & 400,700 & 465,726 & 522,230 & 581,793 & 704,539 \\
\hline \multicolumn{6}{|l|}{ Laos } \\
\hline Neraca perdagangan & $-11,260$ & 319 & 10,333 & $-8,341$ & 8,089 \\
\hline Total Perdagangan & 13,578 & 951 & 14,711 & 15,661 & 12,551 \\
\hline \multicolumn{6}{|l|}{ Singapura } \\
\hline Neraca perdagangan & $-48,431$ & 385,583 & $-203,292$ & $-359,952$ & $-519,702$ \\
\hline Total Perdagangan & $2,437,083$ & $2,836,475$ & $2,156,538$ & $1,856,492$ & $2,003,392$ \\
\hline \multicolumn{6}{|l|}{ Thailand } \\
\hline Neraca perdagangan & 645,718 & 485,399 & 559,362 & 418,997 & 424,580 \\
\hline Total Perdagangan & $2,518,168$ & $2,472,569$ & $2,398,536$ & $2,265,725$ & $2,242,764$ \\
\hline \multicolumn{6}{|l|}{ Vietnam } \\
\hline Neraca perdagangan & 700,774 & $1,151,439$ & $1,692,503$ & $1,959,313$ & - \\
\hline Total Perdagangan & $1,612,250$ & $1,964,185$ & $2,462,809$ & $2,855,935$ & - \\
\hline \multicolumn{6}{|l|}{ Malaysia } \\
\hline Neraca perdagangan & 17,898 & $-52,895$ & $-118,098$ & 113,993 & 115,578 \\
\hline Total Perdagangan & $1,877,566$ & $1,948,359$ & $1,720,950$ & $1,500,851$ & $1,448,788$ \\
\hline \multicolumn{6}{|l|}{ Myanmar } \\
\hline Neraca perdagangan & - & - & - & - & 6,695 \\
\hline Total Perdagangan & - & - & - & - & 58,255 \\
\hline
\end{tabular}

Sumber: Trade Map (2017)

Kanada juga menjadi salah satu negara tujuan ekspor utama untuk 10 produk utama Indonesia, karet, kakao, kertas, alat penerima untuk televisi dan pakaian olahraga. Nilai ekspor produk Indonesia ke Kanada pada tahun 2016 mencapai USD 0,35 miliar sedangkan impornya sebesar USD 1,38 juta.

\section{Hambatan Non-Tarif}

Untuk kawasan ASEAN, Vietnam merupakan negara yang menerapkan NTMs terbesar yaitu sebesar 26.927 
NTMs. Setelah Vietnam, diikuti oleh Indonesia yang menerapkan 21.821 NTMs, Singapura sebesar 17.572,
Thailand sebesar 16.658 NTMs, Brunei Darussalam sebesar 15.384 NTMs, dan Malaysia sebesar 13.360 NTMs.

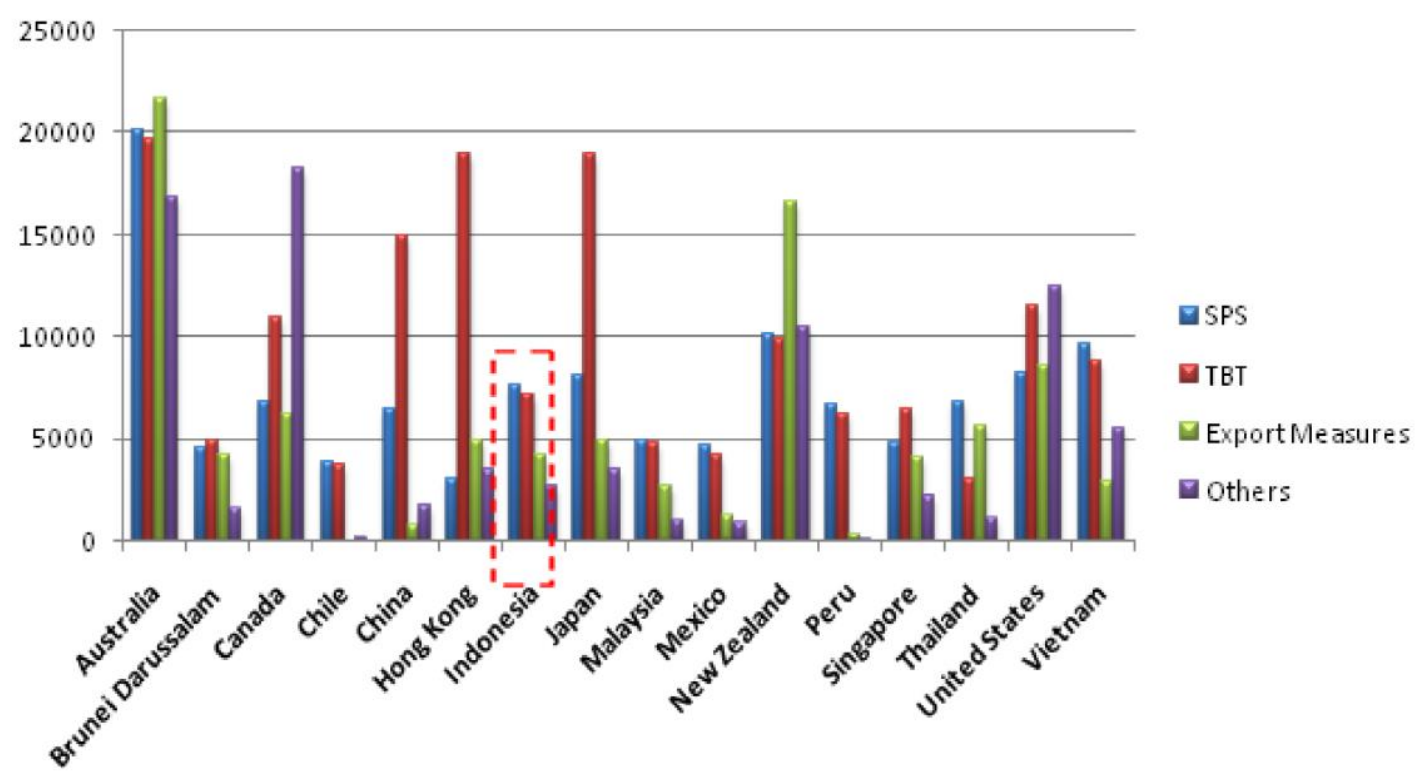

\section{Gambar 1. Tipe NTM yang Dikenakan ASEAN dan Kanada}

Sumber: WITS (2017), diolah

Di kawasan ASEAN, satu-satunya negara yang memiliki nilai coverage ratio tertinggi adalah Vietnam. Total nilai impor Vietnam 100\% terkena satu NTMs berupa TBT, SPS, dan peraturan NTMs lainnya. Hanya $40 \%$ nilai impor Vietnam yang terkena satu NTMs berupa export measures. Indonesia sendiri, dari total nilai impornya, $71 \%$ terkena satu NTMs berupa SPS dan TBT. Sementara untuk export measure, hanya $41 \%$ terkena satu NTMs, dan $50 \%$ dari nilai impor terkena satu NTMs berupa peraturan NTMs lainnya, sedangkan untuk nilai impor Kanada hampir $100 \%$ terkena satu NTMs SPS dan TBT.

\section{Hasil Simulasi GTAP}

Simulasi yang digunakan dalam penelitian adalah penurunan tarif untuk semua komoditi sebesar $90 \%$ jika Indonesia bergabung atau tidak dalam ASEAN-Kanada FTA serta jika terjadi peningkatan fasilitasi perdagangan dan penurunan NTM. Variabel makroekonomi penting untuk melihat dampak dari skema ASEAN-Kanada FTA adalah GDP. Gambar 2 menunjukkan dampak ASEAN-Kanada FTA terhadap GDP. Dari hasil simulasi 
terlihat bahwa jika Indonesia bergabung dalam ASEAN-Kanada FTA, Indonesia akan mendapatkan perubahan GDP riil positif dengan besaran perubahan sebesar $0,03 \%$. Namun jika dibanding dengan negara-negara lain di kawasan ASEAN, maka dampak positif terhadap GDP riil Indonesia adalah yang terkecil.

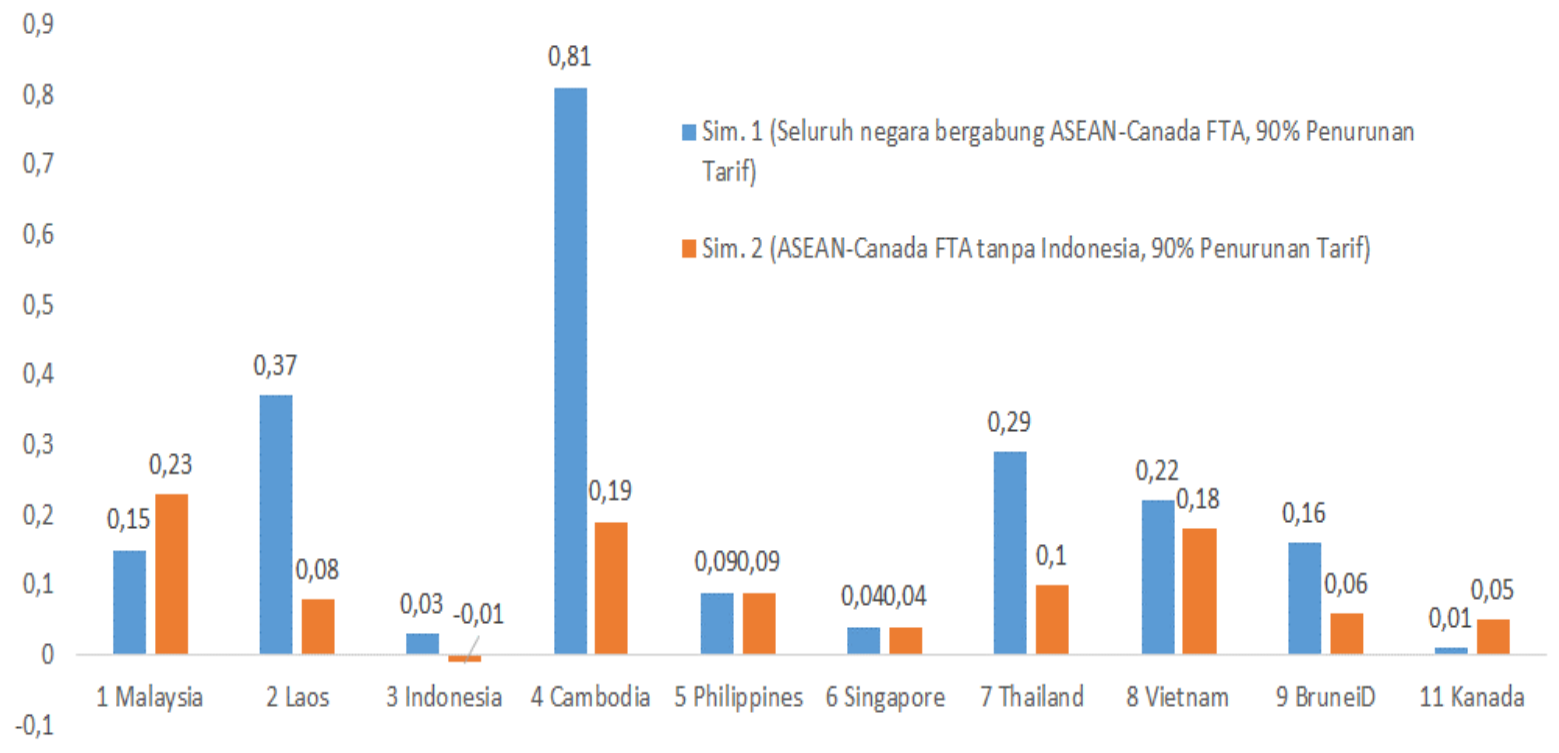

\section{Gambar 2. Hasil Simulasi 1 dan Simulasi 2 terhadap GDP}

Sumber: Hasil Olahan GTAP (2018)

Jika disimulasikan Indonesia tidak ikut bergabung dalam skema ASEANKanada FTA (simulasi 2), maka hasilnya Indonesia akan mengalami penurunan GDP riil sebesar 0,01\% (Gambar 2). Sementara negara-negara ASEAN lain yang melakukan FTA dengan Kanada akan memperoleh peningkatan GDP riil dengan besaran yang bervariasi.
Untuk penurunan NTM dan perbaikan fasilitasi perdagangan (simulasi 3), peningkatan GDP riil diperoleh negara Vietnam, diikuti Malaysia, Thailand, Singapura, bahkan Kamboja, Filipina dan Laos. Peningkatan GDP riil Indonesia sebesar $3,35 \%$ dengan skema simulasi 3 (Gambar 3). 


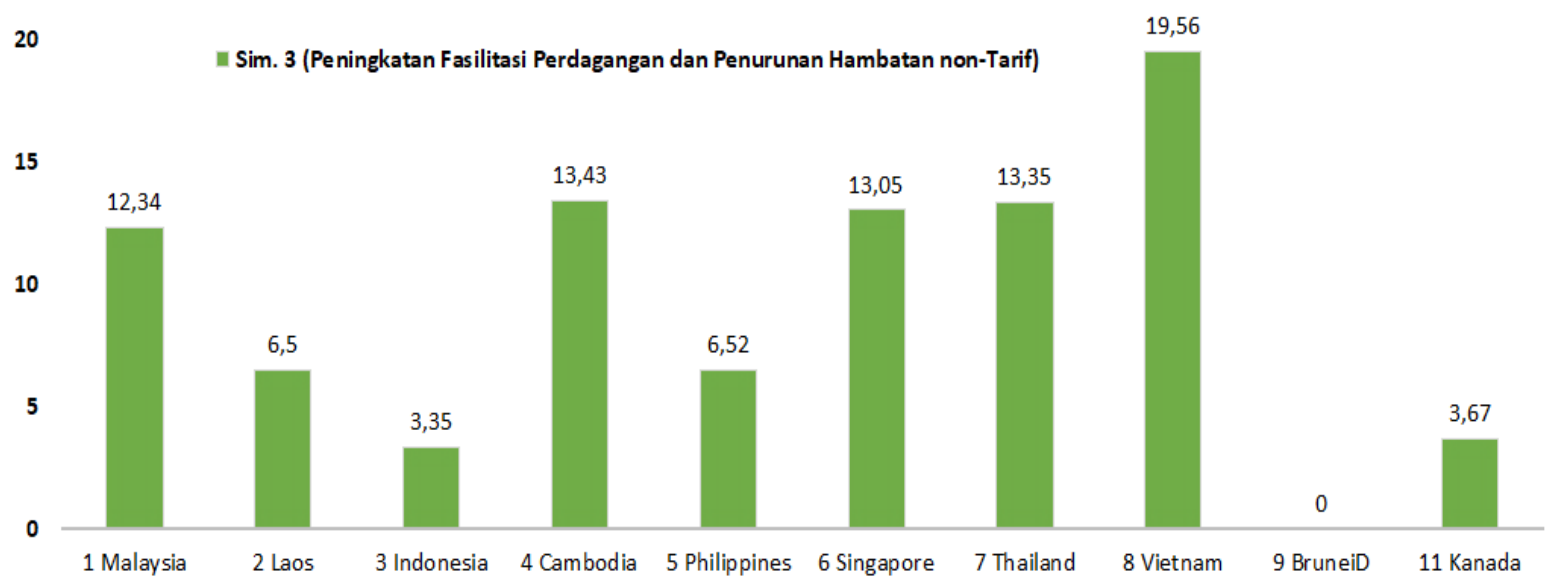

Gambar 3. Dampak Peningkatan Fasilitasi Perdagangan dan Penurunan NTM Terhadap GDP

Sumber: GTAP (2018), diolah

Indonesia tampaknya tidak dapat meningkatkan perdagangan dengan mengandalkan skema penurunan tarif (simulasi 1). Sementara Kanada juga tidak banyak mengambil pertumbuhan dalam negerinya dari skema ini. Kanada diperkirakan mengambil keuntungan lain seperti terbukanya akses pasar yang lebih luas, tidak hanya di pasar ASEAN namun juga kawasan Asia Timur.

Eliminasi tarif, penurunan NTMs, dan peningkatan fasilitasi perdagangan akan mendorong kompetisi dan inovasi serta akan menghasilkan manfaat karena akan meningkatkan produktivitas serta menurunkan biaya (Australian Government Productivity Commission, 2009). Hertel (1997) menyatakan bahwa efek dari regulasi yang berlebihan, atau regulasi yang berbelit dan menyulitkan sehingga menciptakan hambatan perdagangan adalah "cost escalating" (peningkatan biaya yang sangat tinggi).

Tabel 4. Dampak ASEAN - Kanada FTA terhadap Investasi (Perubahan Persentase)

\begin{tabular}{lrrr}
\hline \multicolumn{1}{c}{ Negara } & Sim 1 & Sim 2 & Sim 3 \\
\hline 1 Malaysia & 1,37 & 2.09 & 68,58 \\
2 Laos & 5,28 & 5.74 & 18,70 \\
3 Indonesia & 0,40 & -0.09 & 8,53 \\
4 Kamboja & 13,66 & 14.74 & 60,59 \\
5 Filipina & 0,90 & 1 & 36,86 \\
6 Singapura & 2,08 & 1.99 & 42,75 \\
7 Thailand & 3,06 & 3.38 & 57,81 \\
8 Vietnam & 5,90 & 7.24 & 161,18 \\
9 Brunei D & 2,07 & 2.65 & $-1,44$ \\
10 Kanada & 0,01 & -0.06 & 11,12 \\
11 RestofWorld & $-0,05$ & -0.01 & $-1,59$ \\
\hline
\end{tabular}

Sumber: GTAP (2018), diolah

Efek dari eliminasi regulasi yang berlebihan akan menurunkan biaya, dimana hal ini menjadi daya tarik bagi investor. Hal ini tercermin pada 
peningkatan investasi yang lebih tinggi pada simulasi 3 (Tabel 4).

Skema penurunan tarif, melakukan regulatory reform dari mengurangi NTMs dan peningkatan fasilitasi perdagangan secara komprehensif telah menyediakan ruang untuk peningkatan investasi. Dengan adanya peningkatan investasi di Indonesia dapat memberikan dampak jangka panjang positif terhadap perdagangan. (Safitriani, 2014). Persetujuan untuk meliberalisasi perdagangan di sektor barang dan jasa akan memperlancar dunia usaha untuk melakukan kegiatan perdagangan. Aliran investasi diharapkan akan menjadi semakin tinggi dengan adanya reformasi regulasi, minimisasi resiko ketidakpastian dalam berusaha, dan perbaikan iklim investasi. Bagi Indonesia peningkatan investasi yang tertinggi akan terjadi pada Simulasi 3, yaitu sebesar 8,53\%. Dibanding negara lain maka Vietnam mendapatkan keuntungan tertinggi dalam investasi. Negara Kamboja merupakan negara yang akan mendapatkan peningkatan investasi yang relatif paling besar di hampir seluruh simulasi. Meski tidak mendapat peningkatan investasi yang tertinggi namun Kanada terjadi peningkatan arus investasi sebesar $11,12 \%$.
Dampak Skema Kerja sama ASEANKanada FTA Terhadap Ekonomi Sektoral Indonesia

Hasil simulasi 1 terhadap ekonomi sektoral dengan menggunakan model GTAP (Gambar 4 dan 5) menunjukkan bahwa liberalisasi untuk semua komoditi sebesar $90 \%$ untuk semua komoditas akan memengaruhi kinerja sektoral/ industri dengan dampak yang berbedabeda. Sektor-sektor dengan peningkatan output serta yang mengalami perbaikan yang ditandai dengan peningkatan ekspor dan atau penurunan impor, atau dikatakan potensi keuntungan yaitu sektor kendaraan bermotor, perlengkapan transportasi, perlengkapan medis dan optik, perlengkapan elektronik, produk logam olahan, besi dan baja, mineral non-logam, pakaian, minuman dan produk tembakau serta sayur dan buah. Sedangkan sektor-sektor yang mengalami penurunan output dan yang mengalami penurunan performa yang ditandai dengan penurunan ekspor atau peningkatan impor, atau dikatakan sektor-sektor yang berpotensi mengalami kerugian seperti logam emas, perak dan alumunium, minyak sayur, gandum dan tepung, susu, serat tumbuhan untuk tekstil, daging dan jeroan babi serta industri lain. 

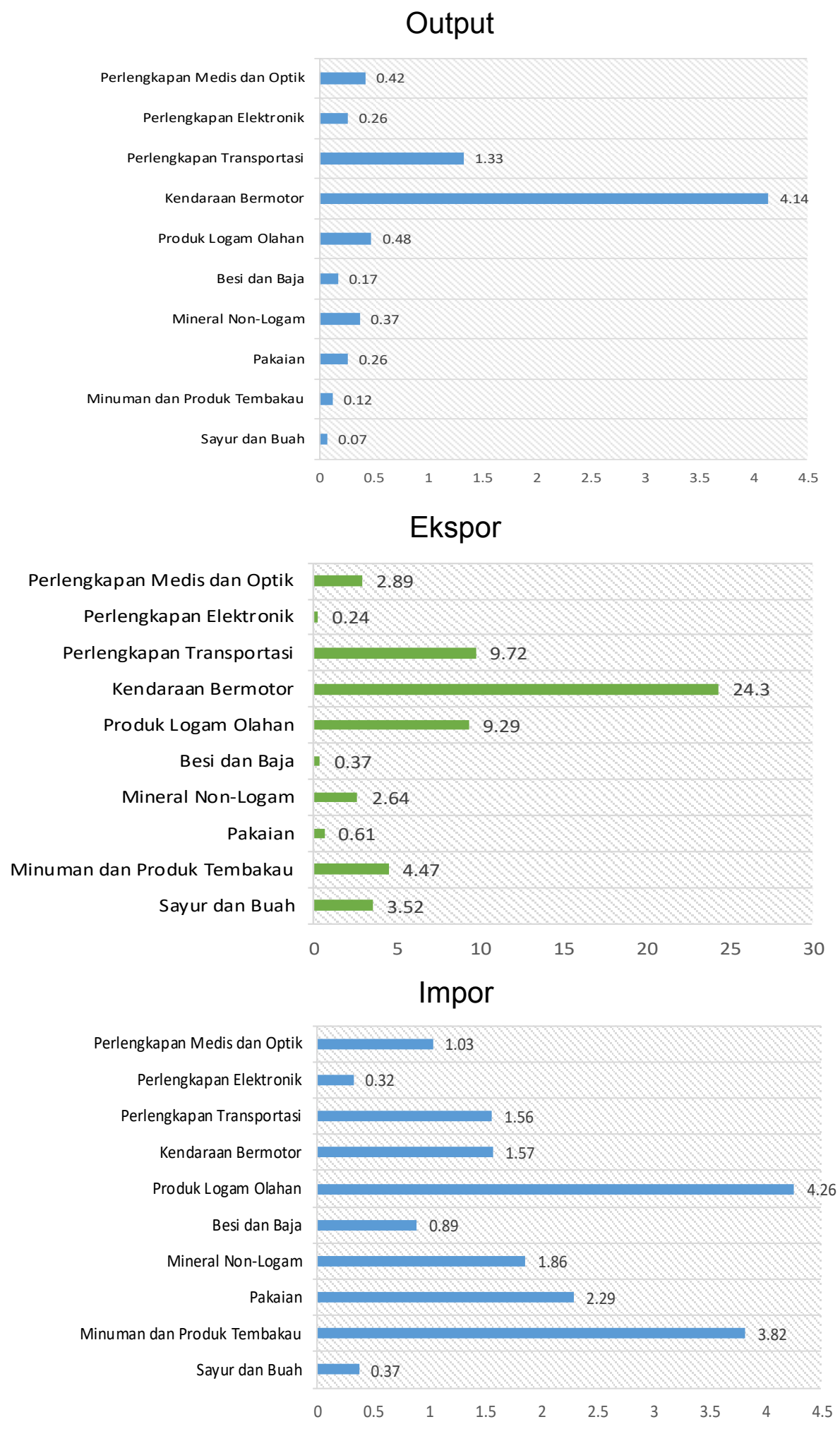

\section{Gambar 4. Sektor yang Mendapat Dampak Positif dalam ASEAN-Kanada FTA (Simulasi 1)}

Sumber: GTAP (2018), diolah 


\section{Output}

Industrilain : Daur Ulang Logam : Emas, Perak, Alumunium

Minyak Sayur Daging dan Jeroan Babi, Olahan Jasa Terkait Aktifitas Perikanan Susu Serat Tumbuhan untuk Tekstil Gandum dan Tepung

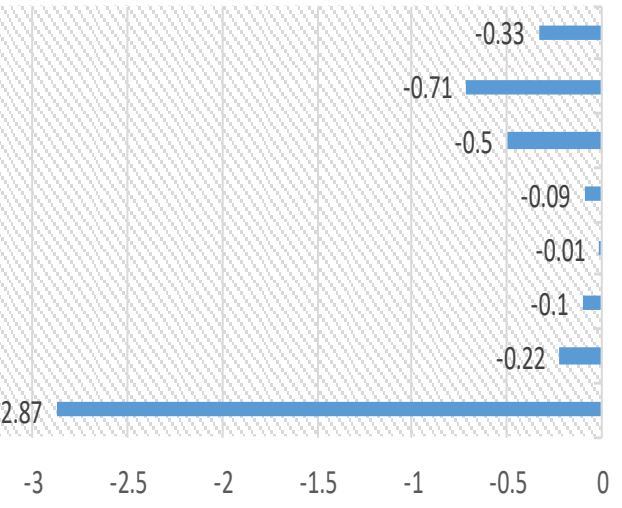

Ekspor

Industri lain : Daur Ulang

Logam : Emas, Perak, Alumunium

$$
\text { Minyak Sayur }
$$

Daging dan Jeroan Babi, Olahaß3.31 Jasa Terkait Aktifitas Perikanan

Susu

Serat Tumbuhan untuk Tekstil Gandum dan Tepung

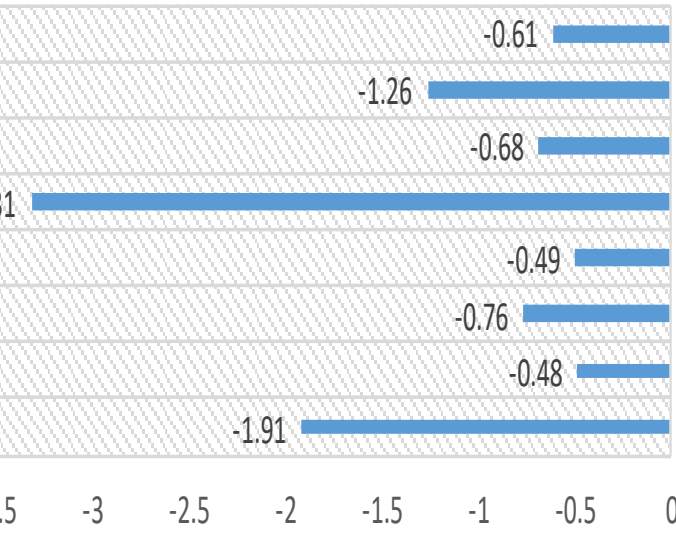

\section{Impor}

Industri lain : Daur Ulang

Logam : Emas, Perak, Alumunium Minyak Sayur

Daging dan Jeroan Babi, Olahan Jasa Terkait Aktifitas Perikanan

Susu

Serat Tumbuhan untuk Tekstil

Gandum dan Tepung

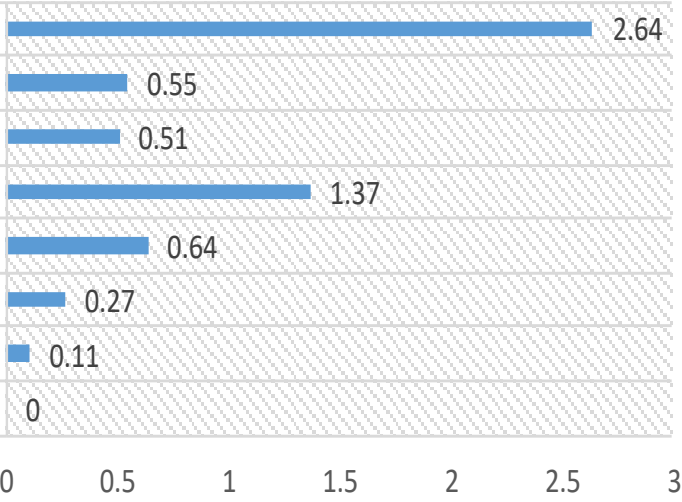

\section{Gambar 5. Sektor yang Mendapat Dampak Negatif dalam ASEAN-Kanada FTA} (Simulasi 1)

Sumber: GTAP (2018), diolah 
Tabel 6. Sektor yang Mendapat Dampak Positif dan Negatif dalam ASEANKanada FTA (Simulasi 3)

\begin{tabular}{|c|c|}
\hline Sektor & Output \\
\hline Construction: building houses factories offices and roads & 7.92 \\
\hline Non-Metallic Minerals: cement, plaster, lime, gravel, concrete & 6.09 \\
\hline Motor Vehicles: cars, lorries, trailers and semi-trailers & 3.86 \\
\hline Wearing Apparel: Clothing, dressing and dyeing of fur & 3.26 \\
\hline Electronic Equipment: office, accounting and computing machinery & -8.62 \\
\hline Chemical Rubber Products: basic chemicals, other chemical & -13.41 \\
\hline Non-Ferrous Metals: production and casting of coppe & -16.94 \\
\hline Sektor & Ekspor \\
\hline Oil: extraction of crude petroleum and natural gas (par) & 33.13 \\
\hline Cattle: cattle, sheep, goats, horses, asses, mules, and hinnies & 27.04 \\
\hline Textiles: textiles and man-made fibres & 26.18 \\
\hline Other Machinery \& Equipment: electrical machinery & 26.02 \\
\hline Raw milk & -6.76 \\
\hline Non-Ferrous Metals: production and casting of copper, aluminium & -8.46 \\
\hline Cane \& Beet: sugar cane and sugar beet & -10.75 \\
\hline Sektor & Impor \\
\hline Leather: tanning and dressing of leather; luggage, handbags & 63.06 \\
\hline Wearing Apparel: Clothing, dressing and dyeing of fur & 53.38 \\
\hline Other Crops: live plants; cut flowers and flower buds; flower & 52.73 \\
\hline Vegetable Oils: crude and refined oils of soya-bean, maize & 52.4 \\
\hline
\end{tabular}

Sumber: GTAP (2018), diolah

Hasil Simulasi 3 (Tabel 5) sektorsektor yang mendapatkan peningkatan output serta ekspor yaitu sektor Konstruksi, Non Metallic Minerals, Motor Vehicle Wearing apparel, oil, Cattle dan tekstil. Sedangkan yang mengalami peningkatan impor yaitu sektor Leather, Wearing apparel, other crops dan soya bean. Berdasarkan hasil turun lapang penulis, sektor-sektor yang mengalami peningkatan impor adalah produkproduk dengan kualitas yang tinggi serta produk yang tidak diproduksi di dalam negeri.

\section{KESIMPULAN DAN REKOMENDASI KEBIJAKAN}

Hasil simulasi CGE perdagangan menunjukkan bahwa jika dilakukan simulasi penurunan tarif $90 \%$ pada kawasan ASEAN-Kanada, Indonesia akan mengalami peningkatan GDP riil, dan investasi. Skenario penurunan NTM yang disertai dengan peningkatan fasilitasi perdagangan akan 
memberikan dampak positif $\mathrm{Hal}$ ini menunjukkan bahwa penurunan NTMs dan perbaikan logistik atau fasilitasi perdagangan diantara kedua belah pihak menjadi faktor terbesar untuk memperoleh keuntungan dari skema ASEAN-Kanada FTA yang bisa dicapai Indonesia. Pada dampak terhadap GDP riil, dibanding negara lain di ASEAN, Indonesia mendapatkan keuntungan relatif lebih kecil dibanding Singapore, Thailand, Vietnam, Malaysia. Bahkan Kamboja akan mendapat keuntungan terbesar untuk investasi dan GDP riil. Indonesia akan mengalami kerugian terbesar jika tidak tergabung dalam ASEAN-Kanada FTA baik dilihat dari GDP riil, maupun investasi.

Berdasarkan hasil simulasi terhadap sektor-sektor Indonesia yang mengalami penurunan output dan peningkatan impor sejatinya merupakan bahan baku dan juga barang modal yang digunakan untuk input industri. Sehingga keberadaannya tetap diperlukan dalam kegiatan impor. Peningkatan GDP riil yang di dapat dari Indonesia berdasarkan simulasi 3 (penurunan NTM dan peningkatan fasilitas perdagangan) mengisyaratkan bahwa fokus kerja sama pada skema ini bagi Indonesia lebih baik diarahkan kepada perbaikan logistik atau trade facilitation lainnya diantara kedua belah pihak dan usaha mengurangi gap kendala non tarif (NTMs).

Dalam skema ini Indonesia dapat memanfaatkan transfer teknologi dari Kanada. Dengan transfer teknologi maka upaya peningkatan produktivitas dapat dicapai. Peningkatan produktivitas diyakini akan meningkatkan output per tenaga kerja untuk menambah kemampuan R\&D di negara-negara ASEAN. Disamping itu, diperlukan juga upaya untuk meningkatkan daya saing sektor/produk Indonesia mengingat dengan skema FTA ini Indonesia harus bersaing dengan negara anggota ASEAN lainnya. Salah satu upaya dalam peningkatan daya saing adalah memanfaatkan transfer teknologi dari Kanada, sehingga diharapkan terjadi peningkatan produktivitas yang pada akhirnya akan meningkatkan output per tenaga kerja dan menambah kemampuan R\&D di negara-negara ASEAN khususnya Indonesia.

\section{UCAPAN TERIMA KASIH}

Penulis mengucapkan terimakasih yang sebesar-besarnya kepada Bapak Djatmiko Bris Witjaksono, Kepala Pusat Pengkajian Kerja Sama Perdagangan Internasional atas arahan dan buah pikiran yang sangat bermanfaat dalam penyelesaian studi ini. 


\section{DAFTAR PUSTAKA}

Aguiar, A, Narayanan, B, McDougall, R. (2016). An Overview of the GTAP 9 Data Base. Journal of Global Economic Analysis, Vol 1 (1), pp. 181-208

Armington, P.S. (1969). A theory of demand for products distinguished by place of production. IMF Staff Papers, 16, pp. 159-178.

Barichello, R.R.\& Yap, J.T. (2010). Three Year ASEAN-Canada Policy Research Programme: A Proposal. Institute of Southeast Asian Studies.

CABC. (2017). The ASEAN Advantage: Exploring Canada's Trade Potential. Canada-ASEAN Business Council, Voncouver.

Economic Research Institute of ASEAN (ERIA) (2018) Joint Feasibility Study for an ASEAN - Canada Free Trade Agreement.

Furkon, Moh. Hami. (2015). Analisis Analisis Dampak Perjanjian ASEANKorea Free Trade Area (AKFTA) Bagi Indonesia: Pendekatan Global Trade Analysis Project (GTAP) Versi 8, Skripsi, Fakultas Ekonomika dan Bisnis, Universitas Diponegoro, Semarang.

Hertel, T.W., and M.E. Tsigas. (1997). "Structure of GTAP", in Hertel, T.W. (ed.),

Global Trade Analysis: Modelling and Applications. Cambridge University Press,

Cambridge.

Hidayat, Agus Syarip. (2016). Dinamika Kerja sama Ekonomi Indonesia Dengan Anggota Organisasi Konferensi Islam (OKI): Potensi dan Pengaruhnya Terhadap Perekonomian Indonesia. Buletin IImiah Litbang Perdagangan, Vol. 10 No.1, Juli 2016.

lanchovichina, E., dan Mcdougall, R (2000). Theoritical Structure of
Dynamic GTAP. GTAP Technical Paper No.17

Itakura, K. (2014). "Impact of Liberalization and Improved Connectivity and Facilitation in ASEAN. Journal of Asian Economics. Volume 35, pp 1106.

Kenichi, Kawasaki. (2014). The Relative Significance of EPAs in Asia-Pasific. RIETI Discussion Paper Series 14-E009. Japan

Laksani, D.D., dan Salam, A.R. (2016). Perkiraan Dampak ASEAN dan Hong Kong Free Trade Area (AHKFTA) terhadap Kinerja Perdagangan Indonesia. Buletin IImiah Litbang Perdagangan, Vol. 10 No.2, Desember 2016.

Manurung, H. (2016). Improving Free Trade Agreement (FTA): A Study on the European Union (EU) - Indonesia Comprehensive Economic Partnership Agreement (CEPA), 2012 - 2016. Working Paper Series School of International Relations President University.

Safitriani, S. (2014). Perdagangan Internasional dan Foreign Direct Investment di Indonesia. Buletin Imiah Litbang Perdagangan, Vol. 8 (1), pp.93-116.

Soesastro, H. (2005). The Evolution of ASEAN+X Free Trade Agreements Implication for Canada. Trade Working Papers No. 21999, East Asian Bureau of Economic Research.

Plummer, M.G., D. Cheong and S. Hamanaka. (2010). Methodology For Impact Assessment of Free Trade Agreement. Manila: Asian Development Bank.

Raihan, S. (2015). "South Asian Economic Union -Challenges and Tasks Ahead". South Asia Economic Journal September 2015. 16: 3S-18S 
Woo, Y.P. (2005). Canada-ASEAN Economic Relations: Assessment and

Prospects. Asia Pacific Foundation of Canada.
Yuventus, E. (2014). Implementasi ASEAN Free Trade Agreement Terkait Kinerja Perdagangan Indonesia: Pendekatan Model Gravitasi. Buletin IImiah Litbang Perdagangan Vol 8 No 1 Juli 2014. 